\title{
肺癌におけるシアリルL $e^{x}-i$ 抗原 $(S L X)$, SSEA-1抗原, フコシルSSEA-1抗原の組織内発現 特に組織分類との関連性について
}

\author{
Immunohistochemical Expression of Sialyl Le ${ }^{\mathrm{x}}-\mathrm{i}, \mathrm{SSEA}-1$ and \\ Fucosyl SSEA-1 Antigens in Various Types of Lung Cancers
}

浅見英一・横瀬智之・伊藤雄二

要旨：SLX, SSEA-1, フコシルSSEA-1抗原の発現を77例の原発性肺癌を対象に免疫組織学的 に検討したＳSLX陽性率は，腺癌 $(78 \%)$ に高率で，特にクララ細胞型・気管支腺型で顕 著であった。扁平上皮癌 $(67 \%)$ では，陽性像が角化細胞にみられ分化度との関連性が示

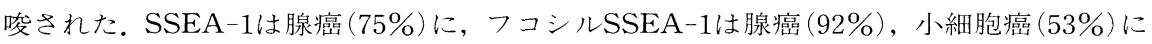
高率であった，以上より，3種の癌胎児性抗原は腺癌の亜型間ないし腺癌以外の組織型 で,その発現に差が認められた。

〔肺癌 $30(4) ： 555 \sim 561 ， 1990 〕$

Key words : Lung cancer, SLX, Immunohistochemistry.

はじめに

シアリルL $\mathrm{Le}^{\mathrm{x}}-\mathrm{i}$ 抗原 $(\mathrm{SLX})$ は肺腺癌患者血清 において高い陽性率を示す癌胎児性抗原である。 しかし，このSLXに対する抗体FH-6を用いて， 肺癌組織での局在を免疫組織化学的に検索する と, 肺腺癌でも組織覀型によりその染色動態が 異なることがわかっている，今回我々は，種々 の原発性肺癌でのSLXの陽性率と局在につい て免疫組織化学的に検討した. また, SSEA-1抗 原，フコシルSSEA-1抗原についても同様の検 討を加えた。

\section{対 象}

対象は原発性肺癌75例 (扁平上皮癌22例, 小細 胞癌 23 例, 腺癌 27 例, 大細胞癌 3 例) 及び肺芽腫 2 例を用いた，各組織型については，肺癌取扱 い規約 ${ }^{1)}$ に沿った。また，発生部位別分類，組織

東京都多摩老人医療センタ一臨床病理科
亜型分類については, 以下の通り行った。

扁平上皮癌は，その発生部位から V 次分岐以 前のものを中枢型， $\mathrm{V}$ 次分岐以後を末梢型とし た. Spindle cell typeについては, 組織型の特 殊性から独立してとりあげ，WHO分類 き診断した. 小細胞癌は, 1988年IASLCの勧告3) に基づき, Pure small cell carcinoma(Pure SCLC), Mixed small cell-large cell carcinoma (Mixed SC/LC) 及びCombined small cell carcinoma (Combined SCLC) に分類した。腺癌 は, Kimula ${ }^{4)}$, Shimosato ${ }^{5)}$ 亜型分類に準じ 5 悪型分類を行い，また胎児肺上皮細胞類似の腺 癌を胎児型とした。

\section{方 法}

$10 \%$ ホルマリン, または $2.5 \%$ グルタールアル デヒドにより固定した肺癌組織をSLXに特異 的な抗体FH-6(大塚アッセイ)を用い, アビジ 
ンービオチン法により免疫 組織化学的に光顕的局在と 陽性度を検討した。また， SSEA -1抗原, フコシル SSEA-1抗原についても， それらを認識する抗体 $\mathrm{FH}$ -2，AH-6(ともに大塚アッ セイ)を用い検討した。な 扮, 染色標本の陽性度の評 価は，それぞれの染色性に より，下記のごとく 4 段階 に分類判定した。

一；腫瘍細胞が全く染色 されていない。

+；25\%末満の腫湯細胞 か染色されている。

$2+; 25 \%$ 以上 $50 \%$ 未満の 腫痬細胞が染色され ている。

$3+; 50 \%$ 以上の腫瘍細胞 が染色されている.

\section{結 果}

I.SLXの陽性率と局在 (Table 1)

FH-6による肺癌組織で の免疫組織化学的検索では, 腺癌において 27 例 中21例 $(78 \%)$ と高い陽性率を示した。覀型別で はクララ細胞型が全例陽性であり，12例中 7 例

Fig. 1. Luminal surfaces of Clara cell subtype showed strong positivity for SLX. ABC method $(\times 200)$.

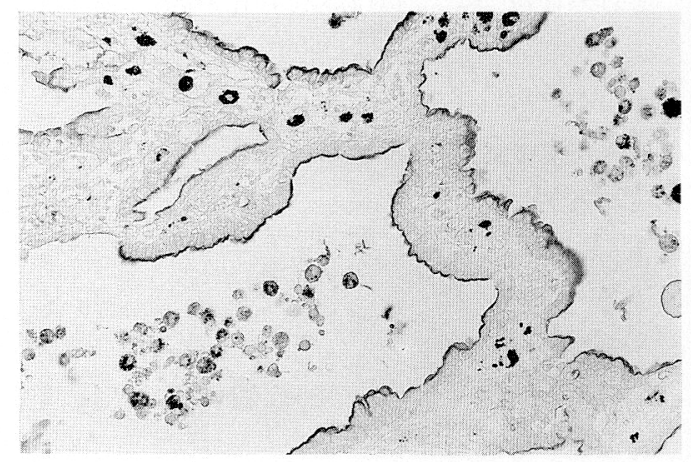

(58\%)は 2 十以上の陽性度を示した (Fig. 1). また，気管支腺型は 3 例中 2 例 $(67 \%)$ の陽性率 を示したが気管支表面上皮型, 杯細胞型ではそ

Fig. 2. Keratinizing cells of squamous cell carcinoma showed positive immunoreactivity for SLX. ABC method $(\times 200)$.

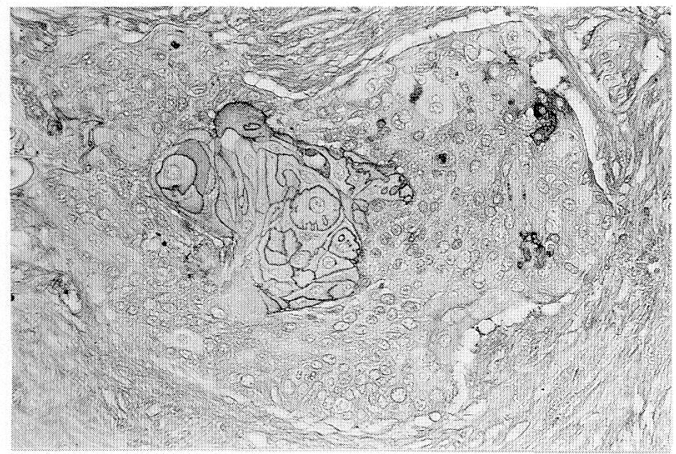


Fig. 3. Large cell components of mixed SC/LC showed positive staining for SLX. ABC method $(\times 400)$.

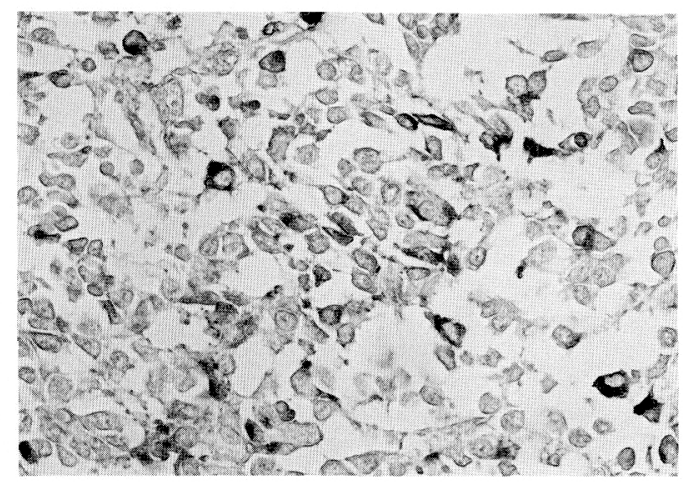

Fig. 4. A luminal surface of epithelial components of pulmonary blastoma showed positive staining, but interstitial components were negative for SLX. ABC method $(\times 400)$.

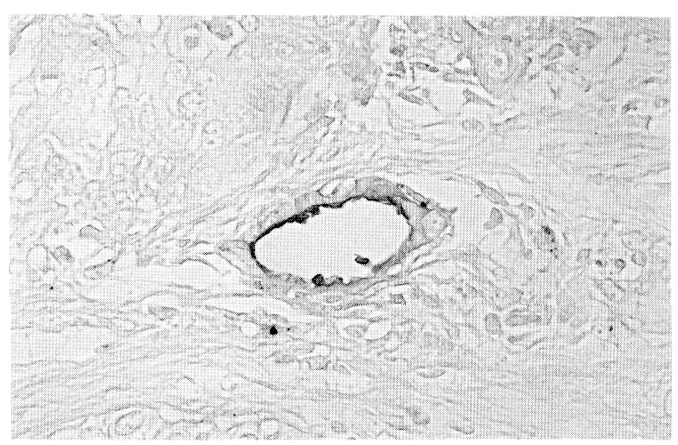

れぞれ43\%，0\%であった。

扁平上皮癌は22例中 14 例

(64\%)の陽性率を示したが, $2+$ 以上の陽性度は認放 れなかった。また，陽性率 は専ら角化部に一致してい た (Fig. 2).

小細胞癌は23例中 3 例 (13\%) と低い陽性率であっ たが，巠型別ではmixed $\mathrm{SC} / \mathrm{LC}$ の大細胞成分に陽 性像が認められた(Fig. 3). 大細胞癌は全例院性であ った。

肺芽腫は， 2 例中 1 例に 管腔形成を示す上皮成分の 管腔側表面に陽性像を認め た(Fig. 4)。間質の細胞は 全て陰性であった。

2. SSEA-I, フコシルSSEA 一、抗原の陽性率と局在 (Table 2, 3)

SSEA-1, フコシル SSEA-1抗体に対する抗体 FH-2, $\mathrm{AH}-6$ による肺癌の

免疫組織化学的検索では, 扁平上皮癌は全体的 に低い陽性率であった。発生部位別に検討する と，AH-6は中枢型が末梢型より高い陽性率を
Table 2. Immunohistochemical analysis of $\mathrm{FH}^{-2}$ (SSEA-1) in lung tumors.

\begin{tabular}{lcrrrrc}
\hline & (Cases) & - & + & $2+$ & $3+$ & Positive cases (\%) \\
\hline Squamous cell carcinoma & $(21)$ & 18 & 3 & 0 & 0 & $3(14)$ \\
Central type & $(11)$ & 9 & 2 & 0 & 0 & $2(18)$ \\
Peripheral type & $(9)$ & 8 & 1 & 0 & 0 & $1(11)$ \\
Spindle cell type & $(1)$ & 1 & 0 & 0 & 0 & $0(0)$ \\
Small cell carcinoma & $(19)$ & 12 & 7 & 0 & 0 & $7(37)$ \\
Pure SCLC & $(10)$ & 6 & 4 & 0 & 0 & $4(40)$ \\
Mixed SC/LC & $(6)$ & 4 & 2 & 0 & 0 & $2(33)$ \\
Combined SCLC & $(3)$ & 2 & 1 & 0 & 0 & $1(33)$ \\
Adenocarcinoma & $(24)$ & 6 & 9 & 6 & 3 & $18(75)$ \\
Clara cell type & $(12)$ & 2 & 7 & 2 & 1 & $10(83)$ \\
Type II & $(2)$ & 1 & 0 & 1 & 0 & $1(50)$ \\
BSE type & $(6)$ & 3 & 0 & 2 & 1 & $3(50)$ \\
Goblet cell type & $(1)$ & 0 & 0 & 0 & 1 & $1(100)$ \\
Bronchial gland type & $(2)$ & 0 & 1 & 1 & 0 & $2(100)$ \\
Unclassified cases & $(1)$ & 0 & 1 & 0 & 0 & $1(100)$ \\
Large cell carcinoma & $(2)$ & 2 & 0 & 0 & 0 & $0(0)$ \\
Pulmonary blastoma & $(2)$ & 2 & 0 & 0 & 0 & $0(0)$ \\
\hline
\end{tabular}

- ; No positive cancer cells. + ; Less than $25 \%$ of cancer cells were positive. $2+; 25 \%$ to $50 \%$ of cancer cells were positive.

$3+;$ More than $50 \%$ of cancer cells were positive.

※ ; Squamous cell carcinoma or adenocarcinoma components in combined SCLS were positive for $\mathrm{FH}-2$ in two cases.

BSE ; Bronchial surface epithelial 
見ると気管支表面上皮型， 気管支腺型で高い陽性率を 示した(Fig. 5).

小細胞癌では, FH-2は 19例中 7 例 $(37 \%), \mathrm{AH}-6$ は19例中10例 (53\%)の陽性 率を示し, 覀型別では, Pure SCLCで高陽性率を 示した(Fig. 6).

大細胞癌，肺芽腫ではと もに，FH-2は全例陰性で あり， AH-6は 2 例中 1 例 (50\%)の陽性率であった。

\section{考 察}

1975年にKöhlerと

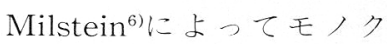
ローナル抗体の作製法が樹 立されて以来多数の抗体か 作製光れてきた。1978年米 国のSolterとKnowles ${ }^{7)}$ は, マウスの着床前の初期胚の 特定の発達段階に特異的に 出現する抗原 Stage-specific embryonic antigen-

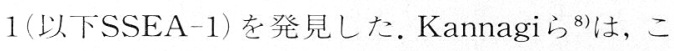
の抗原の全糖鎖構造を解明し，二の抗原は，末 端に $\mathrm{Le}^{\mathrm{x}}$ 抗原構造をもち，側鎖に $\mathrm{i}$ 抗原構造を

Fig. 5. Luminal surfaces of bronchial surface epithelial subtype of adenocarcinoma showed strong immunoreactivity for fucosyl SSEA-1 antigen. ABC method $(\times 200)$.

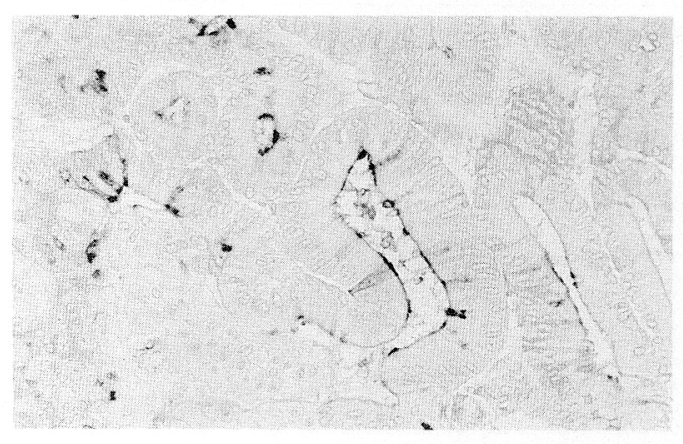

もつことを明らかにした。このSSEA-1抗原は 決して単一の抗原ではなく, 多くの変異体をも つ癌関連性抗原の大群であり, これらの修飾型
Fig. 6. Cell surfaces of small cell carcinoma showed immunoreactivity for fucosyl SSEA-1 antigen. ABC method $(\times 200)$.

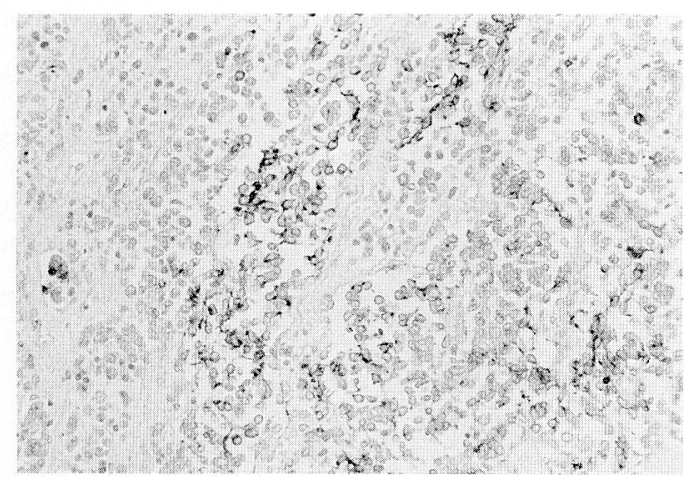


のSSEA-1抗原は, ポリフコース抗原, フコシル SSEA-1抗原, シアリルSSEA-1抗原の各群に 分類される.SSEA-1抗原は, 七上の癌組織にも 大量に蓄積されており, 肺癌, 特に肺腺癌の患 者血清で高值を示すことが報告されている9 .

今回我々は, シアリルSSEA-1抗原, SSEA1抗原, フコシルSSEA-1抗原のそれぞれに対す る抗体FH-6, FH-2, AH-6を用い原発性肺癌で の陽性率と局在を検討したところ, 各組織間で の陽性率に明らかな差が認められた。

腺癌に抢いては，3抗体とも高い陽性率を示 し, 亜型別ではクララ細胞型, 気管支腺型に顕 著であった。一方Miyakeら ${ }^{10} は$, 腺癌において FH-6, AH-6に, 高頻度の発現を示している. また亜型分類に関しても，FH-6のみの検討で あるが, 気管支表面上皮型, クララ細胞型, 気 管支腺型の陽性率は，各々 9 例中 9 例 (100\%), 19 例中 15 例 (79\%)，18例中12例 (67\%) と述べ11， 我々の結果と類似している。 また腺癌において は，陽性率のみならず陽性度も高值であった。 この所見は, 腺癌症例に血清SLXの高值を示す 頻度が他の組織型に比べ高いとの報告9)に対応 する所見と考えられる。

扁平上皮癌では, 腺癌同様に高い陽性率を示 した。しかし $2+$ 以上の陽性度を示寸例は認め られなかった。また陽性像は角化型細胞に限局 していた。この所見は細胞の分化度とSLX発現 の関連を示唆している.

小細胞癌では， 3 種の抗体ともに陽性率は低 值であった。しかしSLXに関しては, mixed SC/LCにおける大細胞成分に陽性像を認めた。 この大細胞成分はpure SCLCに比較してボン
ベシンなどのぺプチドホルモンならびにL dopa decarboxylaseなどのマーカーが消失し， また増殖速度も早く, 放射線治療に抵抗性を示 すなど未分化な組織成分と考之られている ${ }^{12)}$. 一方SLXは高分化腺癌に陽性率が高いと報告 されている10). 今回の検索でも, 腺癌・扁平上皮 癌ともに高分化型にSLX高陽性率であった事 から，SLXが分化度を決定する組織学的指標の 一つとなり得ると考えられる。したがって大細 胞成分はSLX陽性であり，分化型と考えられ， この所見は他のマーカー, 臨床上の予後と異な り，同成分が必ずしも組織学的に未分化とは断 定できない可能性がある。興味ある所見と考之 られ，今後症例を增やし検討する予定である。 肺芽腫は胎児肺に類似した管状構造を形成す る上皮成分と未熟な間葉細胞に類似した介在細 胞より構成され，胎児肺における発育段階との 関連性がよく議論される ${ }^{13)}$. 今回の 2 症例は pseudoglandular phaseであったが，1例の上皮 成分にSLXとフコシルSSEA-1の局在が認めら れた. SSEA-1系統の抗原は七ト肺気管支発生 において特定の発育段階に出現することが知ら れており ${ }^{14)}$, 本抗原が肺芽腫の成熟度の指標と なる可能性も考えられる。

\section{まとめ}

以上, SLXを含むSSEA-1系統の抗原は肺腺 癌において高い陽性率と陽性度を示した。しか し腺癌を亜型に分類し, また腺癌以外の組織型 を詳細に検索すると，その発現の動態に差があ ることがわかった。

\section{文 献}

1) 日本肺癌学会編：臨床・病理肺癌取扱い規約. 金原出版。東京, 1987.

2) World Health Organization: Histological typing of lung tumors, Second edition. 1932, Geneva, WHO, 1981.

3) Yesner, L. : Classification of lung cancer histology. N. Engl. J. Med., 312 : 652-653,

1985.

4) Kimula, Y : A histochemical and ultrastructural study of adenocarcinoma of the lung. Am. J. Surg. Pathol., 2 : 253-264, 1978.

5) Shimosato, Y., Kodama, T., Kameya, T. : Morphogenesis of peripheral type adenocarcinoma of the lung. In : Morphogenesis of 
lung cancer, vol. 1, ed. Shimosato, Y., Melamed, M.R., Nettesheim, P., CRC Press, Boca Raton, P65-89, 1982.

6) Köhler, G., Milstein, C. : Continuous cultures of fused cells secreting antibody of predefined specificity. Nature, $256: 495-497,1975$.

7) Solter, D., Knowles, B.B. : Monoclonal antibody defining a stage-specific embryonic antigen (SSEA -1). Proc. Natl. Acad. Sci., $75: 5565-5569,1978$.

8) Kannagi, R., Nudelman, E., Levery, S.B., et al. : A series of human erythrocyte glycosphingolipids reacting to the monoclonal antibody directed to a developmentally-regulated antigen, SSEA-1. J. Biol. Chem., 257 : 14865-14874, 1982.

9）中井良一, 河原正明, 古瀬清行, 他: 肺腺癌に おけるシアリルSSEA-1抗原 (SLX)の測定の 意義. 肺癌, $29 ： 351-357,1989$.
10) Miyake, M., Zenita, K., Tanaka, O., et al. : Stage-specific expression of SSEA-1-related antigens in the developing lung of human embryos and its relation to the distribution of these antigens in lung cancers. Cancer, Res., $48: 7150-7158,1988$.

11）三宅正幸, 伊藤元彦, 光岡明夫, 他：肺腺癌の 細胞型分類とSSEA-1抗原の免疫組織学的検討. 肺癌， $26 ： 506 ， 1986$.

12) Hirsch, F.R., Matthews, M.J., Aisner, S., et al. : Histopathologic classification of small cell lung cancer. Changing concepts and terminology. Cancer, 62 : 973-977, 1988.

13) Spencer, H. : Pulmonary blastoma. J. Pathol. Bacteriol., 82 : 161-165, 1961.

14）三宅正幸, 神奈木玲児, 岡田慶夫, 他：胎児性 抗原としての Le $\mathrm{e}^{\mathrm{x}}, \mathrm{Le}^{\mathrm{x}}$, Sialyl $\mathrm{Le}^{\mathrm{x}}-\mathrm{i}$ の検討。 肺癌, $27 ： 521,1987$. 


\title{
Immunohistochemical Expression of Sialyl Le ${ }^{\mathrm{X}}-\mathrm{i}, \mathrm{SSEA}-1$ and Fucosyl SSEA-1 Antigens in Various Types of Lung Cancers
}

\author{
Hidekazu Asami, Tomoyuki Yocose and Yuji Ito \\ Department of Pathology, \\ Tokyo Metropolitan Tama Geriatric Hospital
}

\begin{abstract}
We examined the expression of three kinds of carbohydrate embryonic antigens in 77 lung cancers including 22 squamous cell carcinomas, 23 small cell carcinomas, 27 adenocarcinomas, 3 large cell carcinomas and 2 pulmonary blastomas, using specific monoclonal antibodies. Adenocarcinoma showed highest immunoreactivity for SLX (78 $\%)$, and Clara cell and bronchial surface epithelial subtypes were prominently positive ( $100 \%$ and $67 \%$, respectively). Squamous cell carcinoma also demonstrated high positivity for SLX $(64 \%)$ and its immunoreaction was located in keratinizing cells. It was suggested that the immunoreactivity of SLX may be related to differentiation of squamous cell carcinoma. Both SSEA-1 and fucosyl SSEA-1 antigens were observed in adenocarcinoma ( $75 \%$ and $92 \%$, respectively) and the latter also depicted higher immunoreactivity in small cell carcinoma (53\%).

We concluded that not only did three kinds of carbohydrate embryonic antigens show higher positivity in adenocarcinoma of lungs but their expression varied among subtypes of adenocarcinoma and among other histological types.
\end{abstract}

